\title{
The Concept of "New Life" as a Powerful Psycholinguistic Element in the Inaugural Addresses of the U.S. Presidents
}

\section{Концепт “Нове життя"як потужний психолінгвістичний елемент в інавгураційних промовах американських президентів}

Received: June 19, 2020

Accepted: September 7, 2020

\author{
Written by: \\ Maria Shutova ${ }^{1}$ \\ https://orcid.org/0000-0001-7210-0260 \\ Svitlana Mudrynych ${ }^{2}$ \\ https://orcid.org/0000-0002-4524-0935
}

\begin{abstract}
The article deals with the concept of "new life" in the inaugural addresses of the U.S. presidents. A political language, as a reflection of people's behavior in a certain ethnocultural community, is under the consideration. The investigation of political language caused the special approach to the analysis of lexical units that comprise the semantic group "novelty". Based on this analysis a group of words that have the common sema "new" was singled out. The means of expressions and stylistic devices that presidents used to express the idea of "new life" were determined. The presidents make people believe in their ability to take new actions and change the situation, lead the nation to new, better life. Adjective "new" is often used by the presidents in context of the necessity to revitalize old values, to renew the nation spiritually. Analysis of inaugural address of American presidents showed that ideas of "new life" run through the entire speech of every president. In this article the role of the idea of "new life" in inaugural addresses of American presidents and means of its conveying has been studied.

Model of a "new life" can be rather complex, needs more or less strong argumentation. The very word-combination the "better life" predetermines that this life should be different from the existing one, i.e. new. Thus concept of "new life" plays important role in political discourse. Consequently, our research may be understood not only as belonging to a narrow sphere of analysis of political discourse but to wider branch of science linguistic political science.
\end{abstract}

Анотація

У статті розглядається поняття "нового життя" в інавгураційних зверненнях президентів США. Розглядається політична мова як відображення поведінки людей у певній етнокультурній спільноті. Дослідження політичної мови спричинило особливий підхід до аналізу лексичних одиниць, що складають семантичну групу “новизна". На основі цього аналізу було виділено групу слів, що мають загальну сему “новий”. Визначено виражальні засоби та стилістичні прийоми, якими президенти виражали ідею “нового життя”. Президенти змушують людей вірити у свою здатність робити нові дії та змінювати ситуацію, вести націю до нового, кращого життя. Прикметник “новий” часто використовується президентами в контексті необхідності відродження старих цінностей, духовного оновлення нації. Аналіз інавгураційного звернення американських президентів показав, що ідеї “нового життя" проходять через весь виступ кожного президента. У цій статті досліджено роль ідеї “нового життя” в інавгураційних зверненнях американських президентів та засоби іiї передачі.

Модель “нового життя" може бути досить складною, потребує сильнішої аргументації. Саме словосполучення "краще життя" означає, що це життя має відрізнятися від існуючого, тобто має бути новим. Таким чином, концепція "нового життя" відіграє важливу роль у політичному дискурсі. Отже, наше дослідження можна розуміти не лише як приналежність до вузької сфери аналізу

\footnotetext{
${ }^{1}$ Doctor of Philology, Head of Department of English Language and Translation, Faculty of Oriental Studies of the Kyiv National Linguistic University.

${ }^{2}$ Ph.D. (Linguistics), Associate professor, Department of English Language and Translation, Faculty of Oriental Studies of the Kyiv National Linguistic University.
} 


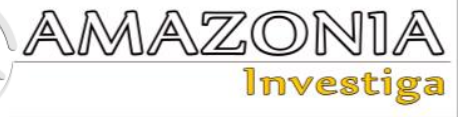

Key words: political language, inaugural address, concept of "new life", sema "new", semantic group "novelty".

\section{Introduction}

Modern linguistics is anthropocentrically oriented, it studies the role of human factor in the language. Political speeches and inaugural addresses attract great attention as far as they are quintessence of political ideas, programs of the country developing for particular period. Consequently the politics' language is under the consideration of many linguists. Works dedicated to the analysis of political language contribute to the study of communicative aspects of language. Some scholars understand the word "new" used in presidents speeches as a symbol of the nation's prosperity (Savoy, 2010), conveying the concept of "new life". We consider this to be a narrow understanding of the problem, at least as far as inaugural addresses is concerned.

\section{Theoretical Framework}

Thus, the researchers (Cruz, 2001; Garabík, 2015; Altmann, 2015; Savoy, 2010; Kyle, 2017; Lim, 2004; Kendall, 1993; Vorobiova, 2000; Kobozeva, 2009) don't analyze all aspects of this problem thoroughly, in our investigation we pay serious attention to the conveying the concept of "new life" in inaugural addresses of the U. S. presidents.

The aim of our research work is to find out the peculiarities of usage of the concept of "new life" in the inaugural addresses of the U. S. presidents.

The main objectives are: to choose the words related to semantic group "novelty"; to compare the meaning of selected words with adjective "new"; to make the componential analysis of these lexemes used by speakers to describe their future policy; to find out the common semantic component of the lexemes, that have the common sema (differential semantic feature) "new"; to define the main functions of political language.

If inauguration is an introduction of the president to the people, it can be successful only in case the president is able to match his image with a stereotyped one of an ideal national leader. політичного дискурсу, а й до більш широкої галузі науки - лінгвістичної політичної науки.

Ключові слова: політична мова, інавгураційна промова, концепція "нового життя”, сема “новий”, семантична група "новизна".

As it is known, language of a speaker or writer reveals his character, outlook, ideology, attitude, estimations (expressive function of language). Image of the author is also an important factor that contributes to integrity of the text (Lim, 2004). Terms 'image of the author' and 'image of the speaker' are used as synonyms. The fact that the speaker (the US president) may not be the author (or the only author) of the text of the speech is ignored because most of the audience do not draw a distinction between the author of the text of the speech and the person who delivers it. Image of the US president is carefully constructed in accordance with social stereotypes of the nation, national values. A politician is not only a symbol by himself; he also lives in the world of symbols. Our investigation of texts of inaugural speeches of the US presidents reveals important features of the image of the ideal president.

\section{Methodology}

The complex methodology of the research is based on the principles of anthropocentrism, cultural determinism, historicism, which ensured the effective implementation of the investigation of the concept of "new life" in inaugural address of the U.S. presidents. This approach has led to a selection of relevant methods and techniques: firstly, we choose the lexemes, using method of selection, which have the common semantic component, corresponding to adjective "new", and devote to semantic group "novelty". To prove it, we, using the comparative method, compare the meaning of choosing words with adjective "new". We use the method of semantic analysis to find out the common semantic component of words, that have the common sema "new". We use quantitative method to add up the quantity of words that have the common sema "new". Repetition can be found in every speech. Repeating words with the sema "new" the presidents make people believe in the ability of the leaders to take new actions and change the situation, lead the nation to a better life. Componential analysis of the words, which the speakers are used to describe their future policy, changes they are going to introduce, vision of the 
situation in the country and abroad, is very important for study the concept of "new life" in inaugural address of the U.S. presidents.

\section{Results and Discussion}

\section{Psycholinguistic Analysis of the U.S. Presidents' Inaugural Speeches.}

Language is a model, a picture that exists between a man and a world, mediating perception of reality. The linguistic world view is historically formed in the collective consciousness of each language and reflects in the language a set of ideas about the world, a certain way of conceptualizing the reality (Bartmiński 2005). Due to the fact that every natural language reflects a certain way of perception and organization (conceptualization) of the world, the values expressed in it form a single system of views, the so-called collective philosophy, which is imposed as a compulsory for all native speakers. The language-specific way of conceptualizing the reality is somewhat universal, somewhat national-specific, so the speakers of different languages can see the world differently, through the prism of their languages. Thus, language of politics becomes not only one of the means that regulate and make the world view, but also the means of determining people's behavior in a certain ethnic and cultural community, the means of ideological influence (Cruz, 2001).

Inaugural speech is a unique chance for every president to address the nation, share his vision of the situation in America and in the world, and to acquaint people with his future policy (The Encyclopedia Americana, 1985: 256).

Many of these ideas are familiar to the public because they were expressed during the president's election campaign. Nevertheless, in the inaugural address they acquire new significance. Ideas expressed by the president of the country will define political course of Government during next years. Moreover, repetition is a very important means of propaganda. Ideas influence people very effectively when they are often repeated. Repetition is also a characteristic feature of ritual discourse. Repetition and parallelism are in every inaugural speech. Parallelism is a syntactic device based on the similarity of structure in a pair or series of related words, phrases or clauses (Kyle, 2017).

One of the types of parallel constructions is used to emphasize the communicative function of the utterance is partial parallelism. While some repetitive units are omitted, the others left in the parallel construction acquire more distinctively and are stylistically marked as compared to the full sentences (Mati, 2012). Such utterance patterns give the speaker a possibility to make his saying more persuasive and leads to the better understanding and memorizing of information.

The stylistic device of enumeration described by R. Köhler (2017) is also syntactically based on partial parallelism. It is caused by the necessity to repeat the statement in different variations, to explain it more carefully that the aims at a better perception, understanding and memorizing the information by audience. Repetitions are considered to be one of the major instruments of persuasion and propaganda because ideas repeated many times separate from the speaker, exist autonomously, then get into subconsciousness of the listeners and become elements of collective belief (Kendall,1993). Repeating words with the sema "new" the presidents make people believe in the ability of the leaders to generate new ideas, take new actions and change the situation. People wait for the presidents to inspire them by promising new opportunities and new rewards. And all the presidents pay much attention to the idea of novelty thus meeting the demand of the public.

The norm of existence of political myth is political discourse. Stereotypes and metaphors, a cliché-reading style of political discourse prevent independent thinking (Kobozeva, 2009). It is worth commenting the ethnolinguistic ideas of E. Sapir (2002) and B. Whorf (Caroll, 1956) (the hypothesis of linguistic relativity), according to which each language has its own ways and means of conceptualization and categorization of the world, and therefore each nation, every nation has its own perceptions of this world, about people as representatives of their culture, and about other ethnic groups. According to these images in different societies there exist the so-called stereotypes (Lippmann, 2004). Political myths predetermine a stereotype of the image of an ideal national leader. Thus, being constructed in accordance with people's desires and aspirations (i.e. with political myths), images of the president become very effective (Vorobiova, 2000).

Criticism of the predecessors, opposing their policy to what is considered to be necessary for the nation is traditionally understood by the audience as a promise to change the situation for better. The method of dramatized contrast is often employed by politicians in their speeches to criticize opponents or predecessors (Simonson, 


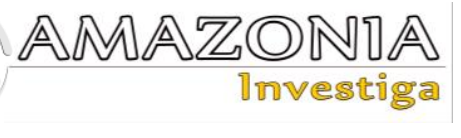

2020). This method makes semantic and stylistic effect of the utterance stronger. Opposing two notions, objects, courses of action attract attention of the audience. Such a contrast is a deliberate exaggeration; its purpose is to dramatize the situation (Garabík, Altmann, 2015).

To make a syntactic analysis of political speech, it's necessary to adopt a semiotic approach, i.e. to analyze grammatical relations between linguistic units from the point of view of semantics, pragmatics, syntax. Relations between the three aspects become clear if syntactic organization of utterances is viewed as determined by the speaker's intentions, because a syntactic form influences the meaning of the utterance and corresponds to the aims of communication. The pragmatic analysis of political texts leads to establishing connections between its pragmatics and semantics, and the syntactic level cannot be studied in isolation from semantic and pragmatic levels (Garabík, Altmann, 2015).

The syntactic analysis of political texts aims at establishing rules of international usage of syntactic units and their relations to communicators (the speaker and the addressee, i.e. at revealing pragmatic content of syntactic structures (Kendall,1993). The pragmatic meaning of syntactic units and their combinations link language signs to the sphere approach to syntax shifts focus of linguistic research from the formal grammatical structure of the utterance to the sphere of modality in language, which makes it necessary to take into account aims and intentions of the speaker (Savoy, 2010). This makes modern syntactic closely connected with the analysis of expressive means and stylistic devices on the syntactic level, i.e. with stylistic syntax. Speaking about political discourse it is necessary to consider main functions of this type of discourse. Political discourse performs the following functions: persuasive, informative, argumentative, persuasive-functional (creation of convincing picture of a new life) The presidents speak about novelty promising changes that lead to a new, better life (as was mentioned, creation of a convincing picture of a new life is one of the main functions of political discourse).

One of the most important factors to emphasize for every politician creating such a picture (model) is novelty and originality of his approach.

It is important for the president to show that he is able to introduce novelty into life of the country and to emphasize his difference from the predecessor. The aim of our research is to study the ways and means of conveying the idea of novelty in the inaugural addresses of the U.S. presidents. The object of our investigation are the texts of five inaugural addresses delivered by Ronald Reagan, George Bush, Bill Clinton. George Bush delivered one inaugural address. Ronald Reagan and Bill Clinton were reelected for the second term and accordingly produced two inaugural addresses each. Thus, we have five speeches under consideration.

Ronald Reagan's First Inaugural Address. Analysis of words that belong to the semantic field "novelty".

In speech the following words are used by the president to convey the idea of "new life": to begin, beginning: And let there be no misunderstandings - we are going to begin to act, beginning today. All must share in the productive way of this new beginning. So, as we begin, let us take inventory. So with all the creative energy at our command, let us begin an era of national renewal;

to renew, renewal: So, with all the creative energy at our command let us begin an era of national renewal. Let us renew our determination, our courage, and our strength. And let us renew our strength and our hope. And as we renew ourselves here in our own land, we will be seen as having greater strength throughout the world; restore (in the form restoring): Steps will be taken aimed restoring the balance between the various levels of government; reawaken: It is time to reawaken this industrial giant...; again: We will again be the exemplar of freedom and a beacon of hope for those who do not have freedom; back: It is time to reawaken this industrial giant, to get government back within its means; new: All must share in the productive work of this "new beginning".

All these lexemes have a common semantic component which corresponds to the adjective "new" and belong to the semantic field "novelty". To prove this we shall compare meanings of the above listed words with those of the adjective "new". The verb to begin has the following meaning: "to be at the point of first contact with; to enter upon; take the first step; do the first or starting part". The substantive beginning is defined as "the action or process of entering upon existence or upon action, or of bringing into existence, commencing, origination". These definitions are very close to those of the adjective new: "now made, or brought into existence, for the first time; of recent origin or growth". Thus, if we begin something (originate it, bring into existence) we introduce something new. Consequently, beginning is introduction of novelty. Such 
definitions allow us to say, that the verb to begin and the substantive beginning have common semantic component equal to the adjective new.

The verb to renew is closely related to the adjective "new". These words have the same root. Latin prefix re- of the verb to renew means "again, anew, originally in cases implying relation to a previous state or condition". The verb to renew has the following meaning: "to make new, or as new, again, to restore the same condition as when new, young, or fresh; to make spiritually new, to regenerate". This is very close to the meaning of the adjective "new" - "coming as a resumption previous act or thing, starting fresh; fresh; restored after demolition, decay, disappearance".

This obvious similarity of meanings, coincidence of words in the definitions prove that the verb to renew and substantive renewal (that means the "act of renewing, or the state of being renewed") both have the sema new and belong to the semantic field "novelty".

To lay emphasis on the idea of "novelty" Ronald Reagan used several stylistic devices and expressive means. The word combination new beginning becomes a metaphor - giving name to era of Reagan's presidency. He proclaimed national renewal one of the most important tasks and used parallelism to attract attention to this idea: let us begin ...let us renew... And let us renew ...

Ronald Reagan's Second Inaugural Address. Analysis of words that belong to the semantic field "novelty".

This speech was delivered by the reelected president. Returning power to the former head of state people naturally expect him to continue his policy. Understanding this, Reagan does not speak about radical changes and concentrates on novelty he has already introduced in life.

... I spoke to you of a new beginning ... But in another sense, our new beginning is a continuation of that beginning created two centuries ago. By 1980, we knew it was time to renew our faith... We are creating a nation once again ... We have begun to increase the rewards for work, savings, and investment... We have already started ... We have made progress in restoring our defense capability. The president usually does not single out his second term as a new stage in the development of the country, but speaks about the years of his presidency as one period:
These will be years when Americans have restored their confidence and tradition of progress;... rebuilding our defenses, our economy, and developing new technologies. These were golden years - when the American Revolution was reborn, when freedom gained new life...

Nevertheless, Reagan's words "There are many mountains yet to climb" are understood as the call to take new actions during next four years of his governing: "We must think anew and move with a new boldness... From new freedom will spring new opportunities for growth... Now we hear again the echoes of our past... The time has come for a new American emancipation..”.

From the above listed examples, we see that the following words are used to convey the idea of "novelty" in the second inaugural address of Ronald Reagan: to begin, beginning, to start, to renew, to create again, to restore, to restate, to rebuild, new, reborn, to hear again, anew. Verbs to begin, to renew, to restore, the substantive beginning, the adverb again were used by the president in his first inaugural address.

Their semantic structure has been already explained. Words that belong to the semantic field "novelty" and are used for the first time in the second speech are: verbs to start, to restate, to rebuild; the adjective reborn, the adverb anew.

The verb to start belongs to the semantic field "novelty" being synonymous to the verb to begin and thus having the sema new as a component of its lexical meaning. Verbs to restate, to rebuild and the adjective reborn belong to this semantic field because of the prefix re- "again, anew" (by analogy with verbs to renew, to restore, to reawaken from first inaugural address).

The adverb anew means "in a few or different way from the previous; newly, freshly, recently". Being closely related to the adjective new it belongs to the semantic field "novelty". The adjective new is used not only in wordcombination new beginning as it was in first inaugural address but also as an attribute to words boldness, freedom and opportunities that symbolize national values and traits of character understood to be necessary for the future development of the country. For the second inaugural address of Ronald Reagan no special metaphor expressing idea of novelty is created. The president twice repeats the metaphor beginning used in his first inaugural speech. 


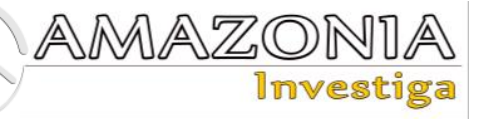

It is used to mark already accomplished tasks that were novel four years ago and to show continuity of American policy thus appealing to traditions of administering and country development. Showing this continuity must be very important for the president because he emphasized the idea three times repeating the substantive beginning in close succession.

George Bush's Inaugural Address. Analysis of words that belong to the semantic field "novelty".

George Bush was the Vice President in Ronald Reagan's administration. He benefited greatly from Reagan's popularity and campaigned by promising voters a continuation of the Reagan's course. But nevertheless in his address to the nation much attention is paid to new ideas and changes. The following words are used to convey the idea of "novelty": refresh (in the form refreshed), reborn, new, (new) breeze, renew (in the form renewed), to begin, again (to make new again, to be new again), to turn.

For a new breeze is blowing, and a world refreshed by freedom seems reborn... A new breeze is blowing, and a nation refreshed by freedom stands ready to push on. A new breeze is blowing, and the old bipartisanship must be made new again. The new breeze blows, a page turns, the story unfolds....freedom is like a beautiful kite that can go higher and higher with the breeze; to begin: And so, there is much to do; and tomorrow the work begins; new: There is a new ground to be broken, and new action to be taken. I am speaking about a new engagement in the lives of others, a new activism, hands-on and involved that gets the job done. The old ideas are new again because they are not old, they are timeless... We need a new engagement, too, between the executive and the Congress...we will continue the new closeness with the Soviet Union: One might say that our new relationship in part reflects the triumph of hope and strength over experience. To the world, too, we offer new engagement and a renewed vow.

All the underlined words belong to the semantic field "novelty". Meanings of the majority of them were considered above. Nevertheless, three words refresh, breeze and to turn are new for us (they were not used by Ronald Reagan). So we shall analyze their meanings here to prove they belong to the semantic field "novelty".

The verb to refresh has the sema new by analogy with words to renew, reborn etc. because of the meaning "again, anew" added by the prefix re-. The substantive breeze among other meanings has the following: "a breath of news". If new information can be called breeze it gives us right to state that this substantive has the sema new (we can define the substantive using the adjective new). The verb to turn can be defined as "to move so as to face in a different direction". Let us compare it with the adjective new meaning "other than the former or old; different from that previously existing, known, or used". To turn is "to move... in a different direction, this movement is different from that previously existing course". So we can understand the meaning of the verb to turn as "to move in a new direction" thus showing that the sema new is a component of its lexical meaning.

The metaphor a new breeze is used in the inaugural address of George Bush. It means that America and the whole world enter new stage of development that things change and the president should respond to these changes. This metaphor is close in meaning to rather popular wind of changed. Being the successor of Ronald Reagan, the continuator of his politics Bush chooses word breeze as a synonym to wind because breeze is understood as a light wind and the new president is not going to introduce radical changes. Compared with a wind of change, new breeze means only slight alteration of the Reagan's course. This metaphor is used four times at the beginning of sentences. George Bush compares history with a book with many pages. This image can be seen in the following sentences combined with the metaphor new breeze: The new breeze blows, a page turns... Therefore, today a chapter begins... This combination of images produces a vivid picture of a new epoch in American history. To emphasize the idea of "novelty" words new and renewed are repeated twice in each of the following three sentences: ...new ground... new action...; new engagement... new activism...;new engagement...renewed vow...

Bill Clinton's First Inaugural Address. Analysis of words that belong to the semantic field "novelty".

In this speech the president proclaims coming of new era in the life of country and calls it a spring: This ceremony is held in the depth of winter. But by the words we speak and the faces we show the world, we force the spring. A spring reborn in the world's oldest democracy, that brings forth the vision and courage the to reinvent America.

Yes, you, my fellow Americans have forced the spring. Three times more the speaker refers to the image of spring using the word season: And so today, we pledge the end to the era of deadlock and 
drift - a new season of American renewal has begun. Now, we must do the work the season demands. I challenge a new generation of young Americans to a season of service... Necessity to renew America is emphasized through the whole speech: Today we celebrate the mystery of American renewal. Our democracy must be not only the envy of the world but the engine of our renewal. To renew America, we must be bold. To renew America, we must revitalize our democracy. To renew America, we must meet challenges abroad as well as at home. My fellow Americans, you, too, must play your part in our renewal. An idea born in revolution and renewed through two centuries of challenge. To convey the idea of "novelty" the president also uses the adjective new, verbs to reform, to rededicate, to give back, to change, the substantive change: When our founders boldly declared America's independence to the world and our purposes to the Almighty, they knew that America, to endure, would have to change. Not change for change's sake but change to preserve America's ideals - life, liberty, the pursuit of happiness.... the urgent question of our time is whether we can make change our friend and not our enemy. Thomas Jefferson believed that to preserve the very foundations of our nation, we could need dramatic change from time to time. Well my fellow citizens, this is our time. Together with our friends and allies, we will work to shape change, let it engulf us. Today, a generation raised in the shadows of the Cold War assumes new responsibilities. And so I say to all of us here, let us resolve to reform our politics... Let us give the capital hack to the people to whom it belongs. Today ...we rededicate ourselves to the very idea of America.

Three times during his speech the president calls the new upcoming era in the life of the country a spring. Three times he refers to this image using the word season. It is interesting that spring is understood not only as "an outburst of fresh development, renewal of life, nature". To comprehend the image completely we should pay attention to the quotation from the Scripture used by the president at the end of the speech: The Scripture says, "And let us not be weary in welldoing, for in due season, we shall reap, if we faint not". We reap in autumn, this is a harvest season. On the contrary, spring is time of hard work in the field, planting seeds to harvest the crops in autumn. The Scripture quotation is figurative but it helps us to understand the metaphor spring as also the call for labor that in due time will produce results. The most widely used words that convey the idea of novelty are the verb to renew (used 3 times), the substantive renewal (used 4 times), the verb renew in the form renewed (used once). Three times the verb to renew is used in parallel constructions. To renew America, we must... This contributes to logical coherence of different parts of the text. The verb to change is repeated twice in one sentence.

Bill Clinton's Second Inaugural Address. Analysis of words that belong to the semantic field "novelty".

In this speech the following words are used to convey the idea of "novelty": the adjective new; the verbs to renew, to reform, to change; the adverb again; modifying verbs to be, to build, to resolve.

The most frequently used words is new: It is our great food fortune that time and chance has put us not only at the edge of a new century, in a new millennium, but on the edge of a bright new prospect in human affairs... When last we gathered, our march to this new future seemed less certain than it does today. We need new government for a new century...And we need a new sense of responsibility for a new century. Our great responsibility is to embrace a new spirit of community for a new century. Great rewards will come to those who can forge new ties that bind together. As this new era approaches we can already see its broad outlines. With a new vision of government, a new sense of responsibility, a new spirit of community, we will sustain America's journey. America of future is called by the president a land of new promise: Guided by the ancient vision of a promised land, let us set our sights upon a land of new promise. The promise we sought in a new land we will find again in a land of new promise. Our land of new promise will be a nation that meets its obligations... And in this land of new promise, we -will have reformed our politics ... Yes, let us build our bridge. A bridge wide enough and strong enough for every American to cross it over to a blessed land of new promise.

In the second inaugural address Bill Clinton touches upon results, he has already achieved during his first term, speaks about the novelty and changes introduced into life: We vowed then to set a clear course to renew our nation. Once again our economy is the strongest on Earth. Once again we are building stronger families, thriving communities. Better educational opportunities, a clearer environment. And once again, we have resolved for our time a great debate over the role of government. Nevertheless, change is understood to be important for the next term too: As times change, so government must change. As the 


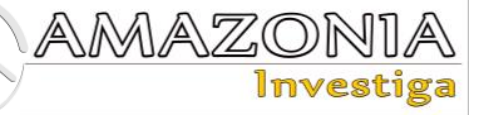

underlined words have the sema new (their meanings were considered above) and belong to the semantic field novelty.

For his second inaugural address, Bill Clinton changed biblical metaphor promised land into a land of promise. It is an old tradition to call America a promised land that started in early days of America's history when first European settlers came to this distant continent. Using the metaphor the land of new promise the president shows that promised land (America) is filled with new meanings, with new opportunities. And here the image of a bridge is introduced by the speaker: Let us build our bridge. A bridge wide enough and strong enough for every American to cross over to a blessed land of new promise. Combination of two images makes the idea of transition of the nation into a new stage more. To emphasize ideas of "novelty" parallel constructions are used in the speech: We need new government/or a new century. We need a new sense of responsibility for a new century. 19 times the adjective new is repeated during the speech.

\section{Conclusions}

In the present research paper, we studied the role of the idea of "new life" in inaugural addresses of American presidents and means of its conveying. We identified twenty-three lexemes (thirteen verbs, two adjectives, five substantives, and three adverbs) with a common semantic component corresponding to the adjective new and showed how they enter the semantic field novelty created by lexical items with the dominant sema new. Analysis of meanings of words with the sema new showed that they denote repetition of actions (correspond to the meaning of the adjective "new" coming as a resumption or repetition of some previous act or thing, starting afresh; restored after demolition, decay, disappearance). Thus, we conclude that Ronald Reagan, George Bush and Bill Clinton present novelty in their speeches as turning back to the past, to old spiritual values and principles of governing. To emphasize ideas of novelty, the presidents use various expressive means and stylistic devices. Each speech contains a metaphor that presents the president's ideas, plans, understanding of the future as full of novelty, new tasks and new achievements. Only Ronald Reagan's second Inaugural Address does not contain new original metaphor to convey ideas of novelty. Repetition or parallel constructions can be found in every speech.

Thus the main task for the presidents is to introduce change not "for change's sake, but change to preserve American ideals - life, liberty, the pursuit of happiness" (Bill Clinton. First Inaugural Address). Change is understood as inherent in the very notion of America foreseen by the founding fathers. Ronald Reagan emphasizes the importance of personal change, change the attitude to Americans within traditionally oriented system. George Bush is very explicit when he states the "the old ideas are new again because they are not old, they are timeless...". This underlines continuity if the American cause. The same idea is expressed by Ronald Reagan's words: “...our new beginning is the continuation of that beginning created two centuries ago" (Ronal Reagan. Second Inaugural Address). The presidents do not only meet the demands of the conservative people but also feel safe presenting their policy as a continuation of the traditional course sanctified by the founding fathers of the country.

Adjective new is often used by the presidents in context of the necessity to revitalize old values to renew the nation spiritually. Spiritual renewal and reestablishing of old values may lead to prosperity but may be considered as the aim in itself. Ability to generate new ideas and to take new actions becomes an important part of image of every president.

Analysis of inaugural address of American presidents shows that ideas of "new life" run through the entire speech of every president. They are found in new sets of values and principles the president wants to introduce or revitalize, in new political decisions he is going to make. The very vision of the situation in the country and abroad can be new, i.e. different from previously accepted. The defined new elements in the president's course, comparative analysis of his policy and the policy of the former Head of state should be carried out together with the study of social, economic and political situation in the country.

Based on this analysis we may single out a group of words that have the common sema new. Thus we shall be provided with objective data to prove statements that the concept of "new life" plays important role in inaugural speeches of American presidents and that ability to introduce novelty into life of the country is an essential component of positive image of the president.

\section{Bibliographic References}

Bartmiński, J. (2005) The linguistic worldview: Ethnolinguistics. Moscow: Indrik. Bush, George W. (1990). State of the Union Addresses of George W. Bush. Project 
Gutenberg

License. www.gutenberg.org/files/5049/5049-h/5049h.htm

Caroll, J. B. (1956). "Introduction". Language, Thought, and Reality: Selected Writings of Benjamin Lee Whorf. Cambridge, Mass.: Technology Press of Massachusetts Institute of Technology. pp. 1-34.

ISBN 978-0-262-73006-8.

Cruz, A. (2001). Language and Political Science. Panama: University of Panama.

Garabík, R. and Altmann, G. (2015). Testing the thematic concentration of text. Journal of Quantitative Linguistics, 22, 215-232.

Kendall, K. (1993). Public Speaking in the Presidential Primaries through Media Eyes. Campaign' 92: New Frontiers in Political Communication. American Behavioral Scientist, 4. https://doi.org/10.1177\%2F0002764293037002 011

Kobozeva, I. (2009). Component analysis of lexical meaning [Komponentnyiy analiz leksicheskogo znacheniya]. Moscow.

Köhler, R. (2017). Exact Methods in the Study of Language and Text. Berlin - New York: Mouton de Gruyter.

Kyle, A.R. (2017). Influence of the Presidential Inaugural Address on Audience Perceptions of Candidate Image and the State of the Nation. United States: Portland State University.
Lim, E.T. (2004). Five Trends in Presidential Rhetoric: An Analysis of Rhetoric from George Washington to Bill Clinton. Presidential Studies Quarterly.

Lippmann, W. (2004) Public Opinion. Project Gutenberg. United States.

Mati, D. (2012). Ideological discourse structures in political speeches. Komunikacija i kultura online, 3, 54-78.

Sapir, E. and Irvine, J. (2002). The psychology of culture: A course of lectures. Berlin: Walter de Gruyter. ISBN 978-3-11-017282-9.

Savoy, J. (2010). Lexical Analysis of US Political Speeches. Journal of Quantitative Linguistics, 2, 123-141. https://doi.org/10.1080/09296171003643205.

Simonson, P. (2020). The Short Story of Rhetorical Theory. Philosophy and Rhetoric, $\begin{array}{lllllll}\text { Vol. } & 3, & 1, & 75 & - & 88 .\end{array}$ https://doi.org/10.5325/philrhet.53.1.0075 https://www.jstor.org/stable/10.5325/philrhet.53 .1 .0075

The Encyclopedia Americana (1985). Danbury, Conn.: Grolier..

Vorobiova, O. (2000). Political vocabulary. Its functions in modern oral and written speech. Arkhangelsk: Pomor M. Lomonosov State University. 